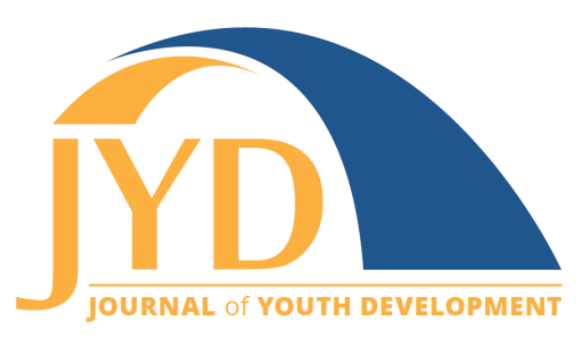

http://jyd. pitt. edu/ | Vol. 13 Issue 3 DOI 10.5195/jyd.2018.620 | ISSN 2325-4017 (online)

\title{
Heart and Shield Family Violence Prevention Program
}

\author{
Jill Baker-Tingey \\ University of Nevada, Reno \\ tingeyj@unce.unr.edu \\ Pamela Powell \\ University of Nevada, Reno \\ powellp@unce.unr.edu \\ Crystal Powell \\ University of Nevada, Reno \\ powellc@unce.unr.edu
}

\section{Abstract}

Children exposed to domestic violence (DV) inadvertently learn behaviors that make them more likely to become victims and/or perpetrators later in life unless they learn skills to address childhood trauma. This article discusses how two rural community needs assessments identified that DV prevention was a highpriority issue, the effects of DV on youth mental and physical health, and the resulting Heart and Shield Family Violence Prevention Program, a Cooperative Extension program designed to strengthen family relationships and break the cycle of violence. Implications for practice include helping youth build healthy relationships, incorporating DV awareness training in staff/volunteer professional development, collaborating with community partners, and advocating for programs that teach positive parent-child interactions.

Key words: domestic violence, healthy relationships, trauma

\section{Introduction}

Growing up in a home with domestic violence (DV) is one indicator that a young person may become a victim or perpetrator in a future intimate partner relationship (Herrenkohl, Sousa,

(cc) EY New articles in this journal are licensed under a Creative Commons Attribution 4.0 License. This journal is published by the University Library System, University of Pittsburgh and is cosponsored by the University of Pittsburgh Press. The Journal of Youth Development is the official peer-reviewed publication of the National Association of Extension 4-H Agents and the National AfterSchool Association. 


\section{Family Violence Prevention Program}

Tajima, Herrenkohl, \& Moylan, 2008). Youth can, however, learn skills to help keep future relationships free from DV. Youth need constructive opportunities to gain knowledge, expand skills, and build healthy relationships in order to thrive. This growth must occur in safe environments for optimal social, emotional, physical, and cognitive development. Parents play a major role in creating this environment. Yet when youth are exposed to trauma, development is interrupted, potentially creating lifelong negative impacts.

For youth exposed to DV, the trauma is compounded because the abuse is inflicted by someone who is supposed to love and protect them. As a result, youth may develop behavioral issues and social and academic challenges. However, traumatized youth can flourish when certain protective factors are in place (Martinez-Torteya, Bogat, von Eye, \& Levendosky, 2009). This paper describes DV's negative effects on youth development and outlines one strengths-based program helping youth and their non-abusive parents create protective factors and break the cycle of violence.

\section{Domestic Violence, Exposure to DV, and Trauma Defined}

DV and trauma are complex, interconnected issues. DV is defined as "a pattern of abusive behavior in a relationship, where one intimate partner uses violence to gain and/or maintain power and control over another" (U.S. Department of Justice, Office of Justice Programs, 2011, p. 1). DV abusive behavior is systematic, and perpetrators use whatever means possible to control their victims' behavior. Society often believes DV involves only spouses or boyfriend/girlfriends; however, DV can also affect roommates, parents, grandparents, and siblings. Other terms for DV include intimate partner violence, domestic abuse, family violence, and family fighting, which are explained through five different types of abuse. These include physical, psychological, emotional, economic, and sexual abuse, as well as stalking or harassment. An abuser may use multiple types of abuse to control his or her victims.

Although DV is most often defined from an adult perspective, youth are also affected. Youth may hear and see the violence and its aftereffects, such as broken furniture or injured family members that occur because of physical or sexual assaults, or be required to participate in subsequent legal disputes (Evans, Davies, \& DiLillo, 2008). Youth are often caught in the crossfire between the perpetrator and the victim, observing their parent being physically threatened or emotionally attacked (Cunningham \& Baker, 2007) and may be forced to watch or inflict the abuse, or be told that they are to blame for it. Some youth may attempt to intervene to protect the victim (Isaac, 2015), which can increase trauma. Trauma, as defined by 


\section{Family Violence Prevention Program}

the National Child Traumatic Stress Network (NCTSN, n.d.c), occurs when a child experiences an intense event that threatens or causes harm to his or her emotional and physical well-being. Complex trauma, such as that experienced with DV, is characterized by exposure to multiple, prolonged and chronic violent events that begin in early childhood, within a family or caregiving system, and can affect development (NCTSN, n.d.b). This trauma, if left unaddressed, may detrimentally affect optimal child development. Fortunately, child, family, and community protective factors can minimize the impact of trauma.

\section{Prevalence of Youth Exposed to DV}

DV affects youth of all ages, socioeconomic backgrounds, cultures, gender, sexual orientations, religions, and nationalities. According to a 2017 United Nations report, 275 million of the world's 2.5 billion youth are abused. It is estimated that of the 74 million youth in the United States, between 3.3 million and 10 million are exposed to DV annually (Annie E. Casey Foundation, 2011) and between 339,000 to 2.7 million are abused (The Body Shop International, Stop Violence in the Home, \& UNICEF, 2011). While the majority of the world's youth are not exposed to DV ( 1 in 9 globally and 1 in 30 in the United States), these numbers may be an underrepresentation, as DV often goes unreported (Felson, Messner, Hoskin, \& Deane, 2002; Felson \& Paré, 2005; Gover, Welton-Mitchell, Belknap, \& DePrince, 2013). Nevertheless, the numbers are staggering, and the potential impact on present and future generations is great. It is estimated that abused youth are three times more likely than youth who are not abused to repeat the cycle of violence as adults, as abusers or victims (Childhood Domestic Violence Association, 2014). In fact, growing up with DV is the most significant predictor of whether or not someone experiences or engages in violence later in life (Martin, 2007).

\section{Effects of DV on Youth Development}

Research has found that youth exposed to DV may experience a range of negative outcomes affecting normal, healthy development. Youth who experience trauma do not "properly pass" through developmental stages, regardless of whether or not they are directly or indirectly exposed to the violence (Isaac, 2015, p. 1). According to Holt, Buckley, and Whelan (2008), youth living with DV are at an increased risk of encountering emotional, physical, and sexual abuse, fueling emotional and behavioral problems. Emotional consequences of concurrent DV and child abuse exposure include isolation, shame, fear, guilt, and low self-esteem. Youth subjected to DV are more likely to have damaged coping skills, hindering their emotional intelligence when compared to their non-exposed counterparts. For example, youth exposed to 
DV react more intensely to conflict than non-exposed youth (Overlien, 2010). When youth are subjected to DV, they are two times more likely to internalize behaviors (e.g., experience depression, inflict self-harm such as cutting, and grapple with eating disorders) and to externalize behaviors (e.g., physical aggression, vandalism, defiance, or bullying) (MartinezTorteya et al., 2009). Youth exposed to violence are $74 \%$ more likely to commit a violent crime (Martin, 2007). Often youth who experience trauma struggle to form secure emotional attachments, have poor conflict resolution skills, and are vulnerable to further victimization or perpetration of violence (Herrenkohl et al., 2008).

\section{Symptoms of Exposure to DV in Youth of Different Ages and Developmental Stages}

Youth react differently to DV depending upon their age and developmental stage (see Table 1). Their coping ability is influenced by the frequency, severity, and duration of DV; their proximity to the abuse; and repeated separations and relocations, as well as their caregivers' responses to the violence (Child Welfare Information Gateway, 2014; NCTSN, n.d.a; Wilson, 2006). However, these symptoms are not exclusive to DV. There can be unrelated stressors, traumas, or developmental issues that account for a child's trouble concentrating. Negative behaviors should be viewed in the context of the child's family's practices (NCTSN, n.d.a). Although very young children, including infants and toddlers, are affected by DV, this paper focuses on youth ages 6-18.

Table 1. Symptoms of Exposure to DV in Youth of Different Ages and Developmental Stages

\begin{tabular}{|c|c|c|}
\hline $\begin{array}{l}\text { Symptoms and/or } \\
\text { reactions to DV }\end{array}$ & School-age children, ages 6-11 & Teens, ages 12-18 \\
\hline Academic & Avoid school; truancy ${ }^{a}$ & $\begin{array}{l}\text { School failure; truancy; }{ }^{\text {a, b }} \text { dropping out } \\
\text { of school }\end{array}$ \\
\hline Cognitive & $\begin{array}{l}\text { Difficulty concentrating on or } \\
\text { completing tasks; }{ }^{\text {a }} \text { difficulty } \\
\text { transitioning from one activity to the } \\
\text { next }\end{array}$ & $\begin{array}{l}\text { Predisposition toward attitudes and } \\
\text { values associated with violence and/or } \\
\text { victimization }^{c}\end{array}$ \\
\hline
\end{tabular}


Table 1 (continued).

\begin{tabular}{|c|c|c|}
\hline $\begin{array}{l}\text { Symptoms and/or } \\
\text { reactions to DV }\end{array}$ & School-age children, ages 6-11 & Teens, ages $12-18$ \\
\hline Emotional & $\begin{array}{l}\text { Preoccupation with worry; concern for } \\
\text { personal safety and safety of family } \\
\text { members; }{ }^{\mathrm{c}} \text { hypervigilance in accurately } \\
\text { or inaccurately detecting threats; }{ }^{\text {d }} \\
\text { Lower recognition, communication, and } \\
\text { regulation of emotions; react } \\
\text { excessively; minimize or maximize } \\
\text { perceptions; detachment }\end{array}$ & $\begin{array}{l}\text { Less likely to trust others; may feel } \\
\text { pessimistic about relationships in } \\
\text { general; }{ }^{\text {e }} \text { concern for personal safety } \\
\text { and safety of family members; } \\
\text { minimize or maximize perceptions; } \\
\text { react excessively }\end{array}$ \\
\hline $\begin{array}{l}\text { Externalizing } \\
\text { behaviors }\end{array}$ & Aggression; bully others; ${ }^{b}$ self-harm ${ }^{d}$ & $\begin{array}{l}\text { Refusal to follow rules; }{ }^{\mathrm{b}} \text { running } \\
\text { away; }^{\mathrm{a}, \mathrm{b}} \text { delinquency; substance } \\
\text { abuse;b, h bully others; }{ }^{\mathrm{c}} \text { may intervene } \\
\text { in physical fights to protect abused } \\
\text { parent; }{ }^{\mathrm{c}} \text { unhealthy sexual activity; } \\
\text { impulsive and/or reckless behavior; }{ }^{\mathrm{a}, \mathrm{h}} \\
\text { carrying a weapon; self-harm; }{ }^{\mathrm{d}} \text { suicide } \\
\text { attempts }\end{array}$ \\
\hline $\begin{array}{l}\text { Internalizing } \\
\text { behaviors }\end{array}$ & $\begin{array}{l}\text { Withdrawal and/or emotional } \\
\text { numbness; }{ }^{\text {a }} \text { cry frequently; vulnerable } \\
\text { to being bullied; }{ }^{f} \text { self-blame or guilt } \\
\text { about the DV; lower self-concept; }{ }^{c}\end{array}$ & $\begin{array}{l}\text { Withdrawal, anxiety, } \\
\text { Depression; }{ }^{a, b, h} \text { vulnerable to being } \\
\text { bullied; }{ }^{f} \text { posttraumatic stress disorders }\end{array}$ \\
\hline Physical & $\begin{array}{l}\text { Frequent headaches; digestive } \\
\text { concerns }^{k}\end{array}$ & Eating disorders ${ }^{j}$ \\
\hline Sleeping & Sleep disruptions; nightmares ${ }^{a}$ & $\begin{array}{l}\text { Sleep more or less than peers; may } \\
\text { feel tired all the time }\end{array}$ \\
\hline Social & $\begin{array}{l}\text { Difficulty with relationships; }{ }^{\mathrm{h}} \text { poor } \\
\text { understanding of social cues; lower } \\
\text { social competency }\end{array}$ & $\begin{array}{l}\text { Involvement in violent or abusive } \\
\text { dating relationships; fighting; poor } \\
\text { peer relationships; }{ }^{\text {a limited }} \\
\text { interactions with friends }\end{array}$ \\
\hline
\end{tabular}

${ }^{a}$ NCTSN (n.d.a). ${ }^{b}$ Child Welfare Information Gateway (2014). 'Cunningham and Baker (2007). dPickens and Tschopp (2017). 'Levendosky, Huth-Bocks, and Semel (2002). ${ }^{\text {fHolt }}$ et al. (2008). 9McCloskey (2011). hNCTSN (n.d.c). 'van der Kolk (2005). jMartinez-Torteya et al. (2009). kStiles (2002). 
Family Violence Prevention Program

\section{Long-Term Consequences of Trauma}

Negative impacts on youth can linger for years after escaping abuse, through post-traumatic stress disorder, chronic health conditions, and an increased likelihood of engaging in risky behaviors (Centers for Disease Control and Prevention [CDC], 2016). Furthermore, abuse can alter a youth's DNA, causing premature aging by 7 to 10 years (Childhood Domestic Violence Association, 2014). In one study, youth exposed to high stress showed neuromolecular changes, increasing their risk for anxiety and depressive disorders (Papale, Seltzer, Madrid, Pollak, \& Alisch (2018). In addition, abuse can damage the prefrontal cortex, the part of the brain that controls decision-making and judgment (Mehta et al., 2014). Left unaddressed, DV increases the likelihood adults will have a mental illness, contract a communicable disease, or develop a chronic disease, thereby reducing quality of life. In fact, adults exposed to DV as children often die earlier than non-exposed adults (CDC, 2016).

The CDC and Kaiser Permanente conducted a 10-year study with 17,000 adults, designed to examine the effects of adverse childhood experiences (ACEs) on adult health. Felitti et al. (1998) found a strong correlation between traumatic childhood exposures and preventable diseases and injuries, including heart, lung, and liver disease; cancer; skeletal fractures; and self-reports of poor well-being. The findings reflected how children often adopt behaviors such as drug abuse, overeating, and other negative coping mechanisms to deal with the stress of abuse, DV, and other family dysfunction. These children also tend to experience anxiety, anger, and depression later in life. Further analyses of the ACEs data found that participants exposed to DV often experience an additional four ACEs, based on a 0-10 scale, as a result of DV exposure. In addition, respondents who reported their mother was a DV victim had at least three additional ACEs. In fact, DV was identified as the ACE least likely to occur in isolation, implying exposed children are more likely to have other ACEs (McGavock \& Spratt, 2017). Other researchers found strong relationships between high ACE scores and the risk for perpetrating DV (Anda et al., 2006). These studies clearly indicate that DV-induced trauma has long-lasting negative impacts in both childhood and adulthood, if left unaddressed.

\section{Heart \& Shield: A Family Violence Prevention Program}

\section{Identifying DV as a High-Priority Issue through Needs Assessments}

Formal needs assessments conducted by land-grant university Cooperative Extension faculty, based in two rural Nevada counties, revealed that DV prevention was a high-priority issue for county residents (Powell, 2003; Powell \& Evans, 2014; Tingey, Smith, \& Singletary, 2012). State 


\section{Family Violence Prevention Program}

and local DV statistics, including DV-related murders, further illuminated the need for Extension programs aimed at reducing DV in the community. As services in rural Nevada are often limited to victim crisis intervention, little prevention education is available for children and their nonabusive parents. Instead of waiting for youth to exhibit risky behaviors or enter the justice system, the assessment authors created a strengths-based program called Heart and Shield: A Family Violence Prevention Program (H\&S).

\section{Participants}

Since 2013, 78 adults and 156 youth in three rural Nevada counties have participated in H\&S educational programming. Participants' age ranged from 8 months to 86 years. The majority of youth were 3 to 12 years old. Adults' average age was 35 years old. Entire families (aunts, grandmothers, and friends) attended the program. Of the 234 participants, 136 were Native American, 49 were Caucasian, 47 were Hispanic, and two were African American. Of the total participants (adults and youth), approximately three-fourths were female and one-fourth were male.

\section{Program Description}

We conducted a review of evidence-based DV prevention programs. Most programs targeted young children and their parents, youth in a school or after-school setting, or teens. Few programs used a family model, involving children of all ages and the non-abusive parent. Of the existing programs that included a parent and youth component, a therapeutic model was used. We chose to adopt a Cooperative Extension prevention-education model, focusing on experiential learning activities for all age groups. Table 2 describes how we designed the H\&S program based on the DV prevention literature.

H\&S teaches youth and adult DV survivors skills to strengthen relationships and break the cycle of violence. Small groups of youth and their non-abusive parents meet weekly for 9 weeks, learning teambuilding, communication, conflict management skills, emotional literacy, positive peer relations, problem solving, and social competence. Young people meet according to age: (a) early childhood - birth to eight years, (b) youth - nine to 13 years, and (c) teens - 14 to 18 years, building skills and competencies through an experiential model. While parents meet in a room separate from the youth, they learn similar skills and strategies to help their children talk about the violence and solve problems related to the trauma. The parent lessons help parents understand children's developmental stages, parenting styles, and ways to guide and direct 


\section{Table 2. Heart and Shield Protective Factors Research Applications}

\begin{tabular}{|c|c|}
\hline $\begin{array}{l}\text { DV literature outlining protective } \\
\text { factors for youth and parents }\end{array}$ & Heart and Shield program application examples \\
\hline $\begin{array}{l}\text { Proactive orientation - taking initiative in } \\
\text { and control of one's own life, including: } \\
\text { - Positive outlook } \\
\text { - Hope } \\
\text { - Belief that one can overcome } \\
\text { challenges } \\
\text { - Internal locus of control } \\
\text { - Self-esteem } \\
\text { - Self-regulation } \\
\text { b }\end{array}$ & $\begin{array}{l}\text { Parents identify qualities they want their children to possess as teens and/or adults. During } \\
\text { the course of the program, parents are reminded of those qualities and what they can do } \\
\text { to help their children. } \\
\text { - Young children, youth, and parents learn to identify and name a variety of emotions and } \\
\text { what they can do to calm themselves when faced with strong emotions. }\end{array}$ \\
\hline Positive interpersonal relationships ${ }^{a}$ & $\begin{array}{l}\text { - A sense of belonging among participants is promoted by guiding each group to develop } \\
\text { ground rules to feel emotionally and physically safe in the program. } \\
\text { - Youth learn how to make friends and practice communication and conflict resolution skills } \\
\text { to maintain friendships. } \\
\text { - Parents and youth learn and practice characteristics of healthy family relationships by } \\
\text { learning the importance of having fun together as a family, giving compliments to one } \\
\text { another, and holding regular family meetings. }\end{array}$ \\
\hline $\begin{array}{l}\text { Social emotional learning programs for } \\
\text { youth, such as empathy, respect, } \\
\text { communication, and conflict resolution } \\
\text { skillsc }^{c}\end{array}$ & $\begin{array}{l}\text { - Group discussions, games, role-play, arts and crafts, community service projects, and } \\
\text { other hands-on activities to teach youth social and emotional skills. } \\
\text { - By sharing ideas and supplies and making things together, youth and parents learn } \\
\text { elements of healthy relationships. }\end{array}$ \\
\hline
\end{tabular}


Table 2 (continued).

\begin{tabular}{|c|c|}
\hline $\begin{array}{l}\text { DV literature outlining protective } \\
\text { factors for youth and parents }\end{array}$ & Heart and Shield program application examples \\
\hline Positive family relationships ${ }^{a}$ & $\begin{array}{l}\text { - At the end of each session, participants rejoin their families and participate in a family } \\
\text { activity, which reinforces concepts taught in the separate groups. } \\
\text { - Providing support and education to parents, helps parents to support their children. }\end{array}$ \\
\hline Parenting styles ${ }^{a}$ & $\begin{array}{l}\text { Parents are taught to: } \\
\text { - Use warm and firm guidance. } \\
\text { - Set routines and clear boundaries for children. } \\
\text { - Distinguish the difference between uninvolved vs. permissive and authoritarian vs. } \\
\text { - authoritative parenting styles } \\
\text { - Identify how the different parenting styles have a direct effect on children's behavior. }\end{array}$ \\
\hline Social support systems ${ }^{a}$ & $\begin{array}{l}\text { - Parents receive information on community resources for themselves and their children. } \\
\text { - Monthly family activities provide an avenue for families to reconnect and support one } \\
\text { another. }\end{array}$ \\
\hline $\begin{array}{l}\text { Early intervention for children exposed to } \\
\text { DV }\end{array}$ & $\begin{array}{l}\text { - Providing educational programming for all ages of children and parents allows the family to } \\
\text { work on skills together, based on children's developmental ages and stages. }\end{array}$ \\
\hline Communication and listening skills ${ }^{\mathrm{a} ; \mathrm{c}}$ & $\begin{array}{l}\text { - Teaching parents how to talk with their children about the family fighting they may have } \\
\text { experienced, helps parents open lines of communication and express care and concern. } \\
\text { - Active listening skills and the using "I" messages to share feelings teaches families positive } \\
\text { ways they can interact with one another without resorting to yelling, fighting, and other } \\
\text { behaviors that close constructive communication. }\end{array}$ \\
\hline
\end{tabular}

aBenavides (2015); ' Lee (2001); 'CDC (2017) 


\section{Family Violence Prevention Program}

children, which may help non-abusive parents regain their authority and parental role. In homes where DV is present, the abuser may undermine the victim's authority, weakening the attachment between non-abusive parent and child (Jaffe \& Crooks, 2005).

The H\&S curriculum is being finalized for publication to be used in future programs. Retrospective pre-program/post-program knowledge gain questionnaires and behavior change instruments were also developed for the program.

Appendix A provides a summary of $\mathrm{H} \& \mathrm{~S}$ program topics and activities, while Appendix $B$ includes a sample agenda for one program meeting. To support a reconnection between family members, each class ends with a fun, group activity that incorporates lesson plan objectives and is led by the parents with facilitator assistance. Families also participate in a monthly, H\&Sled group activity to increase family cohesion, such as attending community events as a group, making holiday decorations for their home, creating stepping stones for a local DV shelter, or going on a nature hike.

The program is staffed by one program director (who is an Extension faculty member), one parent facilitator, and one children's facilitator, with one or two assistant children's facilitators, and one youth facilitator at each site. Program directors also served as parent and youth facilitators. The U.S. Department of Agriculture, National Institute of Food and Agriculture, Children, Youth, and Families At-Risk program funded H\&S for five years. During the 5-year grant, an evaluation specialist and a technology specialist also provided expertise. One of the sites is continuing the program beyond grant funding due to strong community support. Extension faculty partnered with school counselors, law enforcement, DV advocates, social workers, tribal council, prosecutors and judges, youth development organizations, and family resource centers to recruit participants and provide stakeholder input.

\section{Program Evaluation}

Nine H\&S cohorts have completed the program. A total of 78 adults participated; however, due to unforeseen family events (e.g., visitation, relocation, or transportation), not all participants attended each class; this is often consistent with challenges families recovering from DV encounter. Therefore, not all participants were able to complete each evaluation instrument. $\mathrm{H} \& \mathrm{~S}$ evaluators initially used an 18-question 4-H Common Measures (CM) pre-post survey required by the funder. As $\mathrm{CM}$ questions could not be modified, the H\&S staff chose to use a multi-method evaluation approach that included exit interviews, end-of-session evaluation, 


\section{Family Violence Prevention Program}

behavioral observation, and a retrospective pretest-posttest, along with the funder-mandated instrument, to improve program delivery and make appropriate curriculum revisions. The exit interview and common measures evaluation instruments and research procedures were approved through the University of Nevada, Office of Research Integrity to ensure that correct investigative protocols were maintained throughout the entire process to protect respondents' confidentiality. To inform curriculum development and program modification, faculty observed behavioral changes and conducted retrospective pretest-posttests and end-of-session evaluations.

\section{Exit Interviews}

At the end of each 9-week session, 35 adults shared their thoughts on preventing DV and raising resilient youth. When asked, "What do you think are the most important things you can do to help your children build healthy relationships free from DV?", parents overwhelmingly responded, "attend the H\&S classes." Parents identified the following program topics as the most useful in helping their children become resilient: (a) typical child development and behaviors; (b) development and behaviors of children exposed to DV; (c) parenting styles; parent-child interactions and its effect on youth development; (d) building family routines; and (e) modeling healthy relationships. Parents identified communication as a key component for a strong family and commented:

- "The different topics helped my family grow closer and healthier together."

- "We are definitely more communicative. When we feel something is [wrong], we are able to problem solve. We share affection more on a daily [basis], we're more productive, more understanding, and we're better listeners."

- "Before the program, we did not spend time together as a family. Since we've been involved with this program, we have a family activity at least three times a week!"

\section{Behavioral Observations}

Faculty and staff observed the following behavioral changes in youth $(n=156)$ and parents $(n$ $=78$ ) over the course of the session:

- Chaotic interactions improved after implementing routines, thereby increasing family functioning and reducing behavior issues.

- Parents remained calm and employed positive guidance when their children exhibited challenging behaviors, helping their children stay on task. 
- Parents increased awareness and attention to self-care, improving their ability to better care for their children.

- Youth's ability to name emotions or describe their feelings about different experiences and generate solutions to solve problems increased during session.

- Family activities became easier to lead as the program progressed.

Families continue to participate in monthly family activities after they complete the program. While new families have enrolled in the classes, those that chose to repeat the class experienced a higher level of family cohesiveness and communication, and a marked reduction in disagreements between parents and children during class. Parents reported a positive difference in how their children respond to them and the family.

\section{Retrospective Pretest-Posttest}

A retrospective pretest-posttest was administered in 2017, which was year 4 of the pilot program. Because of implementing this method in the final 2 years of the pilot program, the number of participants $(n=7)$ was too small to conduct a statistical analysis. However, seven respondents indicated their knowledge sufficiently increased from the beginning, to the end of the session. When asked, "was there anything that was especially helpful to you," parents responded that learning to listen before trying to find an immediate solution, finding positive alternatives for behavior, resources offered, and the emotional and developmental effects of family fighting [on children] were the most helpful aspects. Parents overwhelmingly stated that a positive aspect of the classes was "seeing other parents struggle, [all of us] talking about it, and supporting each other!"

\section{End of Session Evaluation}

During the first year of program education, evaluators asked participants $(n=5)$ to rate the activities used in class to inform program development and included 27 Likert-type scale activity indicators and three open-ended questions. In addition, facilitators kept field notes to track participant progress. Of the 27 activity indicators, 20 received a 4.00 rating or higher on a scale of 1-5, with 1 being "Very Unhelpful" and 5 being "Very Helpful." Responses centered on (a) communication, including using good listening skills, and learning how to talk to children about previous family fighting; (b) H\&S take-home activities; (c) end-of-class family activities; (d) support from other participants; and (e) that confidentiality was respected. For example, one 


\section{Family Violence Prevention Program}

parent stated, "These [H\&S] topics have been very helpful in helping me to talk to and understand my child."

Following the program's completion, parents indicated they are better able to understand their children's feelings and requested additional practice and/or information on self-care, and "I"messages, a tool used to enhance communication, assertiveness, and conflict resolution. Moreover, the parents shared their appreciation, for example stating, "Thank you, I can really see a difference in my family." Youth also indicated that they learned how to communicate their feelings with others and use "I" messages and words that open communication. In addition, youth felt they improved their ability to build friendships, work as a team, and solve problems.

\section{Funder Mandated Survey-4-H Common Measures (CM) Pre-Post Survey:}

The CM instrument, administered to parents, included 18 questions about parent/child relationships. A total of 23 adults and six youth completed the CM pre-post instruments from 2015-2017. Descriptive statistics software (SPSS 25.0 Software, 2017) was used to analyze the results. Cronbach's coefficient alpha was used to estimate reliability of the Likert-type scale survey items for the quantitative measures. The Cronbach score was high $(r=.931)$ indicating a high level of survey reliability (Santos, 1999). A Wilcoxon non-parametric statistical query was used for the quantitative data analysis. When combining CM survey results, the following questions realized a marked improvement $(p<.05)$ in mean score when comparing pre and post mean scores:

- "My child and I have warm, intimate moments together."

- "I believe in praising a child when he/she is good and think it gets better results than punishing him/her when he/she is bad."

- "I feel that a child should have time to daydream, think, and even loaf sometimes."

- "I joke and play with my child."

- "I make sure that my child knows that I appreciate what he/she tries to accomplish."

These responses are encouraging, because children experiencing DV are often victims of harmful parenting. Thus, it is critical that they experience appropriate praise and caring interactions with compassionate adults. Because families in DV situations may be conditioned to behave in a controlled manner, they may not realize the importance of imagination as a critical component to recovery. Provided with an understanding of authoritative parenting styles, parents are better equipped to help build their child's self-esteem and foster stronger family relationships. 
While the remaining $13 \mathrm{CM}$ questions did not realize statistical significance, literature indicates that a higher level of learning may occur in parenting classes than what the evaluations reveal (Brook, Akin, Lloyd, Bhattarai, \& McDonald, 2016; Hill \& Betz, 2005). Parenting class participants often rate their knowledge lower on the postsurvey than on the presurvey. Highrisk parents who have not participated in a program like $H \& S$ rate themselves higher on a presurvey. It is only after a course like H\&S, where topics are explored in greater detail, that participants realize how much more can be learned. Thus, parents rate their knowledge on the postsurvey lower, not remembering ratings on their presurvey. Therefore, a multi-method approach was critical to demonstrating whether the program was successful.

\section{Discussion}

\section{Lessons Learned}

During program implementation, unexpected issues emerged, requiring H\&S staff to re-evaluate program delivery methods and consult further with expert collaborators. The following points are examples of how we resolved some of these challenges:

- As the social stigma of DV often inhibits victims from seeking help for themselves and their children, varied recruitment methods were necessary to reach participants. Flyers were sent home with elementary students, and brochures and posters were displayed in doctors' offices, grocery stores, and governmental agencies. DV advocates, school counselors, social workers, law enforcement officers, church leaders, tribal council members, nonprofit organizations, and elected officials attended a stakeholder meeting before each session to learn more about the program and helped staff promote H\&S. In rural communities, staff promoted the program through newspaper articles, social media, and television and radio appearances. Some participants were referred by family members or friends.

- Staff provided hands-on activities at community events to introduce the program. Asking adults to share the program with a friend experiencing DV was met with more enthusiasm than directly asking someone if he or she was interested in H\&S.

- The H\&S program involved the non-abusive parent and children. Key informant interviews indicated the program content and class discussions could inadvertently encourage the abuse to continue or escalate if the abuser attended. For this reason, parents who were still living with their abuser were not recruited to participate in the program. 
- In order to participate fully in the classes, families needed time after leaving the abuser and entering the program to address basic needs such as employment, housing, child care, legal issues, and counseling.

- Support persons who provided child care (e.g., parent's mother, aunt or uncle, or friend) often accompanied the family to the H\&S classes. These support persons also gained parenting skills, many reporting they were DV survivors as well.

- Serving a light, family-style meal enhanced family interactions. Staff sat with families to encourage communication and model positive guidance techniques.

- Incorporating games, object lessons, scenarios, role-play, and discussions into lessons helped youth foster healthy relationships.

- Modifying class activities to accommodate participant needs (e.g., work and visitation schedules, sick children, transportation conflicts, relocation, etc.), provided additional support and education so that participants did not fall behind. Providing parents with information on typical development and development impacted by DV helped parents understand what they could do now to prevent future exposure, learn how to openly communicate with their children, and find community resources for their children.

\section{Implications for Practice}

Professionals can play an important role in preventing DV, protecting youth, helping families build healthy relationships, and end the cycle of violence:

1. Participate in professional development opportunities, including webinars and online research, to learn about safety planning, local laws governing DV, programs and services, and violence prevention to meet the needs of families affected by DV. See Appendix $\mathrm{C}$ for resources.

2. Use staff with strong social/emotional skills who can communicate empathy and hope, without judgment, to youth and their parents to facilitate the classes.

3. Initiate self-care strategies (Pickens \& Tschopp, 2017) to reduce stress and maintain or enhance personal health and well-being. Model self-care strategies and teach them to youth and parents to help manage challenging emotions and behaviors.

4. Engage youth and parents in open and deep dialogue. Teach parents active listening skills and how to talk with their children about family fighting. For coping to occur, it is essential that parents learn how to create a safe environment (Osofsky, 2003), establish routines, and communicate feelings. Pekel, Roehlkepartain, Syvertsen, \& Scales (2015) revealed that parents who report stronger relationships with their children are more 
Family Violence Prevention Program

likely to report their children are on track in taking responsibility, managing emotions, and being concerned for others.

5. Communicate to parents and youth that staff are mandated reporters and must report suspected child abuse and neglect.

6. Recognize that although a family may not be living with the abuser, they may continue to experience coercive behavior. Implement program safety and confidentiality practices to provide a secure environment.

7. Provide community resource lists containing contact information on mental health, school, housing, food security, healthcare, after-school programs, legal assistance, and DV advocates to assist families in seeking needed support.

8. Create local coalitions comprised of professionals from multiple disciplines and a full range of service systems (e.g., law enforcement, court systems, health care, schools, child and family services, and DV programs). Enlist families and community members to assess local challenges and resources, develop strategies, carry out coordinated responses to children exposed to violence, and promote awareness of the DV issue.

\section{Conclusion}

Youth need opportunities to grow in an environment free from violence (The Body Shop International, 2006). How a child reacts to and recovers from a traumatic situation is based upon how their non-abusive parent responds. This paper described H\&S classes conducted by the University of Nevada Cooperative Extension that were designed specifically to strengthen family relationships and help foster resilient behavior. Research indicates that the occurrence of DV can be reduced; harmful, long-lasting effects can be prevented; and families can be strengthened by teaching social-emotional skills to youth and teaching healthy relationships and parenting skills to parents in family-based programs (CDC, 2017). By advocating for funding and support for programs that teach parenting skills and positive parent-child interactions, caring professionals can foster the well-being of youth exposed to DV (Lyon, Perilla, \& Menard, 2016). Through education, intervention, and family support, all of us can empower victims and communities to create safe, caring neighborhoods and provide families with the resources and skills necessary to break the cycle. 


\section{Acknowledgments}

This material is based upon work supported by the National Institute of Food and Agriculture (NIFA), U.S. Department of Agriculture (USDA), under Agreement No. USDA/CSREES Award No. 2013-41520-20936.

Any opinions, findings, conclusions or recommendations expressed in this publication are those of the author and do not necessarily reflect the view of the U.S. Department of Agriculture.

\section{References}

Anda, R. F., Felitti, V. J., Bremner, J. D., Walker, J. D., Whitfield, C., Perry, B. D., . . Giles, W. H. (2006). The enduring effects of abuse and related adverse experiences in childhood: A convergence of evidence from neurobiology and epidemiology. European Archives of Psychiatry and Clinical Neuroscience, 256, 174-186. doi: 10.1007/s00406-005-0624-4

Annie E. Casey Foundation. (2011). The changing child population of the United States: Analysis of data from the 2010 census. Retrieved from http://www.aecf.org/resources/the-changing-childpopulation-of-the-united-states $L$

Benavides, L. E. (2015). Protective factors in children and adolescents exposed to intimate partner violence: An empirical research review. Child and Adolescent Social Work Journal, 32, 93-107. doi: 10.1007/s10560-014-0339-3

The Body Shop International, Stop Violence in the Home, \& UNICEF. (2006). Behind closed doors: The impact of domestic violence on children. Retrieved from https://www.unicef.org/media/files/BehindClosedDoors.pdf

Brook, J., Akin, B. A., Lloyd, M., Bhattarai, J., \& McDonald, T. P. (2016). The use of prospective versus retrospective pretests with child welfare-involved families. Journal of Child and Family Studies, 25, 2740-2752. doi: 10.1007/s10826-016-0446-1

Centers for Disease Control and Prevention. (2016). About adverse childhood experiences study. Retrieved from https://www.cdc.gov/violenceprevention/acestudy/about_ace.html

Centers for Disease Control and Prevention. (2017). Preventing intimate partner violence. Retrieved from https://www.cdc.gov/violenceprevention/pdf/ipv-factsheet.pdf

Child Welfare Information Gateway. (2014). Parenting a child who has experienced trauma. Washington, DC: U.S. Department of Health and Human Services, Children's Bureau.

Childhood Domestic Violence Association. (2014). Ten startling statistics about children of domestic violence. Retrieved from https://cdv.org/2014/02/10-startling-domestic-violence-statistics-forchildren/ 
Cunningham, A., \& Baker, L. (2007). Little eyes, little ears: How violence against a mother shapes children as they grow. Retrieved from Centre for Children and Families in the Justice System website: http://www.lfcc.on.ca/wp-content/uploads/2017/02/Little-Eyes-Little-Ears_-HowViolence-Against-a-Mother-Shapes-Children-as-they-Grow.pdf

Evans, S. E., Davies, C., \& DiLillo, D. (2008). Exposure to domestic violence: A meta-analysis of child and adolescent outcomes. Aggression and Violent Behavior, 13(2), 131-140.

Felitti, V. J., Anda, R. F., Nordenberg, D., Williamson, D. F., Spitz, A. M., Edwards, V., . . Marks, J. S. (1998). Relationship of childhood abuse and household dysfunction to many of the leading causes of death in adults: The adverse childhood experiences (ACE) study. American Journal of Preventive Medicine, 14(4), 245-258. doi: 0.1016/S0749-3797(98)00017-8

Felson, R. B., Messner, S. F., Hoskin, A. W., \& Deane, G. (2002). Reasons for reporting domestic violence to the police. Criminology, 40(3), 617-647. Retrieved from https://www.researchgate.net/publication/229574900_Reasons_for_Reporting_and_Not_Reportin g_Domestic_Violence_to_the_Police

Felson, R., \& Paré, P. P. (2005). The reporting of domestic violence and sexual assault by nonstrangers to police. Retrieved from https://ncjrs.gov/pdffiles1/nij/grants/209039.pdf

Gover, A. R., Welton-Mitchell, C., Belknap, J., \& Deprince, A. P. (2013): When abuse happens again: Women's reasons for not reporting new incidents of intimate partner abuse to law enforcement. Women \& Criminal Justice, 23(2), 99-120. doi: 10.1080/08974454.2013.759069

Herrenkohl, T. I., Sousa, C., Tajima, E. A., Herrenkohl, R. C., \& Moylan, C. A. (2008). Intersection of child abuse and children's exposure to domestic violence. Trauma, Violence, and Abuse, 9(2), 84-99. doi: $10.1177 / 1524838008314797$

Hill, L. G., \& Betz, D. L. (2005). Revisiting the retrospective pretest. American Journal of Evaluation, 26(4), 501-517. doi: 10.1177/1098214005281356

Holt, S., Buckley, H., \& Whelan, S. (2008). The impact of exposure to domestic violence on children and young people: A review of the literature. Child Abuse and Neglect, 32, 797-810. doi: 10.1016/j.chibu.2008.02.004

Isaac, L. (2015, June). Domestic violence in families: Theory, effects, and intervention. Retrieved from http://www.socialjusticesolutions.org/2015/06/25/domestic-violence-families-theory-effectsintervention/

Jaffe, P. G., \& Crooks, C. V. (2005). Understanding women's experiences parenting in the context of domestic violence: Implications for community and court related service providers. Washington, DC: Violence Against Women Online Resources. Retrieved from http://citeseerx.ist.psu.edu/viewdoc/download?doi=10.1.1.192.3729\&rep=rep1\&type=pdf

Lee, M. Y. (2001). Marital violence: Impact on children's emotional experiences, emotional regulation and behaviors in a post-divorce/separation situation. Child and Adolescent Social Work Journal, 18(2), 
Family Violence Prevention Program

137-163. Retrieved from https://web-a-ebscohost-

com.unr.idm.oclc.org/ehost/pdfviewer/pdfviewer?vid=1\&sid=d99a1bbb-0574-4ced-831363004ef173fa\%40sessionmgr4007

Levendosky, A. A., Huth-Bocks, A. C., \& Semel, M. A. (2002). Adolescent peer relationships and mental health functioning in families with domestic violence. Journal of Clinical Child Psychology, 31(2), 206-218. doi: 10.1207/S15374424JCCP3102_06

Lyon, E., Perilla, J., \& Menard, A. (2016). Building promising futures: Guidelines for enhancing the response of domestic violence programs to children and youth. Futures Without Violence: National Resource Center on Domestic Violence. Retrieved from https://www.futureswithoutviolence.org/building-promising-futures/

Martin, B. F. (2007). What is the impact of childhood domestic violence? Retrieved from Childhood Domestic Violence Association website: https://cdv.org/what-is-cdv/the-\%20impact/

Martinez-Torteya, C., Bogat, G. A., von Eye, A., \& Levendosky, A. A. (2009). Resilience among children exposed to domestic violence: The role of risk and protective factors, Child Development, $80(2)$, 562-577. doi: 10.1111/j.1467-8624.2009.01279.x

McCloskey, L. A. (2011). The impact of intimate partner violence on adolescents. In S. A. GrahamBerman \& A. A. Levendosky (Eds.), How intimate partner violence affects children: Developmental research, case studies, and evidence-based intervention (pp. 225-246). Washington, DC: American Psychological Association.

McGavock, L., \& Spratt, T. (2017). Children exposed to domestic violence: Using adverse childhood experience scores to inform service response. British Journal of Social Work, 47, 1128-1146. doi: 10.1093/bjsw/bcw073

Mehta, D., Klengel, T., Conneely, K. N., Smith, A. K., Altmann, A., Pace, T. W., \& Binder, E. B. (2014). Childhood maltreatment is associated with distinct genomic and epigenetic profiles in posttraumatic stress disorder. National Academy of Sciences of the United States of America, 110(20), 8302-8307. doi: 10.1073/pnas.1217750110

National Child Traumatic Stress Network. (n.d.a). Ages and stages of development: Symptoms of exposure. Retrieved from http://www.nctsn.org/content/ages-and-developmental-stagessymptoms-exposure

National Child Traumatic Stress Network. (n.d.b). Complex trauma. Retrieved from http://www.nctsn.org/trauma-types/complex-trauma

National Child Traumatic Stress Network. (n.d.c). What is child traumatic stress? Retrieved from https://www.nctsn.org/what-is-child-trauma/about-child-trauma

Osofsky, J. D. (2003). Prevalence of children's exposure to domestic violence and child maltreatment: Implications for prevention and intervention. Clinical Child and Family Psychology Review, 6(3), 161-170. doi: 10.1023/A:1024958332093 


\section{Family Violence Prevention Program}

Overlien, C. (2010). Children exposed to domestic violence: Conclusions from the literature and challenges ahead. Journal of Social Work, 10(1), 80-97. doi: 10.1177/1468017309350663

Papale, L. A., Seltzer, L. J., Madrid, A., Pollak, S. D., \& Alisch, R. S. (2018). Differentially methylated genes in saliva are linked to childhood stress. Scientific Reports, $8(10785), 1-8$. doi: 10.1038/s41598-018-29107-0

Pekel, K., Roehlkepartain, E. C., Syvertsen, A. K., \& Scales, P. C. (2015). Don't forget the families: The missing piece in America's effort to help all children succeed. Minneapolis, MN: Search Institute.

Pickens, I. B., \& Tschopp, N. (2017). Trauma-informed classrooms. Reno, NV: National Council of Juvenile and Family Court Judges. Retrieved from http://www.ncjfcj.org/sites/default/files/NCJFCJ_SJP_Trauma_Informed_Classrooms_Final.pdf

Powell, P. (2003). Churchill County: What do you think? Results from a needs assessment conducted by University of Nevada Cooperative Extension (UNCE Special Publication 04-15). Reno: University of Nevada Cooperative Extension.

Powell, P., \& Evans, W. (2014). Results of a 2013 Churchill County needs assessment (UNCE Special Publication 14-12). Reno: University of Nevada Cooperative Extension.

Santos, J. R. A. (1999). Cronbach's alpha: A tool for assessing the reliability of scales. Journal of Extension, 372). Retrieved from https://www.joe.org/joe/1999april/tt3.php/journal-currentissue.php

Stiles, M. M. (2002). Witnessing domestic violence: The effect on children. American Family Physician, 66(11), 2052-2067. Retrieved from https://www.aafp.org/afp/2002/1201/p2052.html\#

Tingey, J., Smith, M., \& Singletary, L. (2012). Results of a mailed survey: Priorities for Elko County (UNCE Special Publication 12-02). Reno: University of Nevada Cooperative Extension.

United Nations Population Division. (2017). World population prospects 2017: Annual population by age group: Both sexes. Retrieved from https://esa.un.org/unpd/wpp/Download/Standard/Population/

U.S. Department of Justice, Office of Justice Programs. (2011). Office of Justice Programs fact sheet: Domestic violence. Retrieved from https://ojp.gov//newsroom/factsheets/ojpfs_domesticviolence.html

van der Kolk, B. (2005). Developmental trauma disorder. Psychiatric Annals, 35(5), 401-408. doi: 10.3928/00485713-20050501-06

Wilson, K. J. (2006). When violence begins at home: A comprehensive guide to understanding and ending domestic violence. Alameda, CA: Hunter House, Inc. 


\section{Appendix A}

\section{H\&S Program Topics and Activities}

\begin{tabular}{|c|c|c|c|c|}
\hline & \multicolumn{2}{|r|}{ Adults } & \multicolumn{2}{|r|}{ Youth } \\
\hline & Topic & Activities & Topic & Activities \\
\hline $\begin{array}{l}-1 \\
\text { y d } \\
\stackrel{d}{3}\end{array}$ & Team building & $\begin{array}{l}\text { Family Name Tags; Introductions; review } \\
\text { meeting format and parent binder; } \\
\text { strengthening family relationships } \\
\text { brainstorming and discussion; ground rules; } \\
\text { adding fun into family interactions }\end{array}$ & $\begin{array}{l}\text { Get acquainted and } \\
\text { team building }\end{array}$ & $\begin{array}{l}\text { Introductions; ways to work together; } \\
\text { individual spotlights; tower building }\end{array}$ \\
\hline 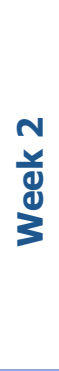 & Communication & $\begin{array}{l}\text { Good listening skills; how to talk with children } \\
\text { about family fighting; how to encourage } \\
\text { children to talk about family fighting; work in } \\
\text { pairs to identify children's feelings based on } \\
\text { their responses and behaviors; the importance } \\
\text { of talking with children about DV }\end{array}$ & Communication & $\begin{array}{l}\text { Non-verbal communication (charades); } \\
\text { verbal communication (draw a picture, } \\
\text { based on verbal instructions); good } \\
\text { listening skills (giving and receiving } \\
\text { instructions from a partner, sitting back } \\
\text { to back) }\end{array}$ \\
\hline $\begin{array}{l}\text { m } \\
\text { J } \\
\text { J }\end{array}$ & Emotion Commotion & $\begin{array}{l}\text { Emotion identification; helping parents manage } \\
\text { their emotions; physical indications that signal } \\
\text { feelings; importance of managing feelings; } \\
\text { keeping calm when under pressure; healthy } \\
\text { ways to relieve stress; ways to help children } \\
\text { manage their emotions and find ways to calm } \\
\text { themselves }\end{array}$ & Emotion Commotion & $\begin{array}{l}\text { Brainstorm, identify, and name emotions; } \\
\text { group emotions under general headings } \\
\text { (sticky wall and word chain); emotion } \\
\text { identification by naming feelings for each } \\
\text { statement and decode messages by } \\
\text { naming true feelings in scenarios }\end{array}$ \\
\hline
\end{tabular}


Family Violence Prevention Program

\begin{tabular}{|c|c|c|c|c|}
\hline & \multicolumn{2}{|r|}{ Adults } & \multicolumn{2}{|r|}{ Youth } \\
\hline & Topic & Activities & Topic & Activities \\
\hline 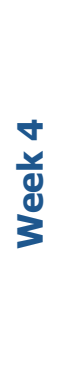 & $\begin{array}{l}\text { Puzzling Problems; } \\
\text { Successful Solutions }\end{array}$ & $\begin{array}{l}\text { Assertiveness; sharing feelings without blaming } \\
\text { by using "I" messages; problem solving with } \\
\text { children: talking about the problem, listening } \\
\text { to children's perspectives, brainstorming, } \\
\text { selecting, and evaluating solutions; family } \\
\text { meetings }\end{array}$ & Emotion Regulation & $\begin{array}{l}\text { Individual feelings influence the group } \\
\text { (room temperature); emotion } \\
\text { regulation: how we talk to ourselves } \\
\text { impacts how we respond to situations } \\
\text { (balloon opposites- providing positive } \\
\text { statements to negative feelings) }\end{array}$ \\
\hline 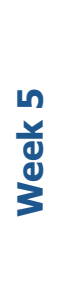 & $\begin{array}{l}\text { Child Development: } \\
\text { Here's looking at } \\
\text { your kid }\end{array}$ & $\begin{array}{l}\text { Typical developmental milestones; how child } \\
\text { development may be affected by DV; } \\
\text { community resources; strategies parents can } \\
\text { use to help children exposed to DV; } \\
\text { establishing routines }\end{array}$ & Fantastic Friendships & $\begin{array}{l}\text { Qualities of a good friend; using } \\
\text { encouraging words vs. demeaning } \\
\text { words; "I" messages; make talking } \\
\text { feathers/sticks }\end{array}$ \\
\hline 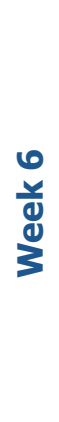 & $\begin{array}{l}\text { Parenting Styles: } \\
\text { Parents make a } \\
\text { difference }\end{array}$ & $\begin{array}{l}\text { Parenting styles: uninvolved, permissive, } \\
\text { authoritarian, and authoritative; matching } \\
\text { children's behaviors with parenting styles; } \\
\text { establishing age-appropriate rules }\end{array}$ & $\begin{array}{l}\text { Puzzling Problems; } \\
\text { Successful Solutions }\end{array}$ & $\begin{array}{l}\text { Personal stress symptoms; make stress } \\
\text { balls; "I" messages; problem solving } \\
\text { steps: talking about the problem, } \\
\text { listening to other's perspectives, } \\
\text { brainstorming, selecting, and } \\
\text { evaluating solutions; working } \\
\text { cooperatively; solution scenarios }\end{array}$ \\
\hline
\end{tabular}


Journal of Youth Development | http://jyd.pitt.edu/ | Vol. 13 Issue 3 DOI 10.5195/jyd.2018.620

Family Violence Prevention Program

\begin{tabular}{|c|c|c|c|c|}
\hline & \multicolumn{2}{|r|}{ Adults } & \multicolumn{2}{|r|}{ Youth } \\
\hline & Topic & Activities & Topic & Activities \\
\hline $\begin{array}{l}\hat{y} \\
\text { d } \\
\text { zon }\end{array}$ & $\begin{array}{l}\text { Tips on guidance } \\
\text { and discipline }\end{array}$ & $\begin{array}{l}\text { Guidance tips to help children succeed; using } \\
\text { positive discipline when children don't follow } \\
\text { rules; Dear Annie: advice for handling common } \\
\text { behavior challenges; helping children grow into } \\
\text { happy, healthy people; family yoga }\end{array}$ & $\begin{array}{l}\text { Cool, Calm, and } \\
\text { Collected }\end{array}$ & $\begin{array}{l}\text { Staying calm under pressure } \\
\text { (brainstorm ways to calm down; what } \\
\text { would you do if?); yoga (youth learn } \\
\text { yoga poses and prepare to teach them } \\
\text { during the family activity) }\end{array}$ \\
\hline \begin{tabular}{l}
$\infty$ \\
y \\
\multirow{d}{J}{} \\
3
\end{tabular} & Healthy relationships & $\begin{array}{l}\text { Qualities of a healthy relationship; } \\
\text { strengthening relationships with children; } \\
\text { appreciating children's efforts and encouraging } \\
\text { their persistence; family compliment catch }\end{array}$ & Healthy Relationships & $\begin{array}{l}\text { Self-esteem: identify positive personal } \\
\text { attributes; empathy: write notes to } \\
\text { parents and siblings; identify ways to } \\
\text { be friendly and helpful; bullying } \\
\text { prevention and assertiveness } \\
\text { discussion and scenarios, includes } \\
\text { cyberbullying; identify characteristics of } \\
\text { healthy relationships (Red Light, Green } \\
\text { Light); teen dating violence prevention }\end{array}$ \\
\hline $\begin{array}{l}\text { a } \\
\text { d } \\
\text { d }\end{array}$ & $\begin{array}{l}\text { Strengthening } \\
\text { Families }\end{array}$ & $\begin{array}{l}\text { Program review and evaluation; family } \\
\text { celebration for completing the program; } \\
\text { inexpensive games families can replicate at } \\
\text { home; preview and invitation to the monthly } \\
\text { "Family Night Out" activities }\end{array}$ & Radical Review & $\begin{array}{l}\text { Program review and evaluation } \\
\text { (Jeopardy, Graffiti Wall); giving and } \\
\text { receiving compliments (Hot Seat); } \\
\text { giving advice for other youth who may } \\
\text { join H\&S; write thank you notes to } \\
\text { program sponsors }\end{array}$ \\
\hline
\end{tabular}


Journal of Youth Development | http://jyd.pitt.edu/ | Vol. 13 Issue 3 DOI 10.5195/jyd.2018.620

Family Violence Prevention Program

\section{Appendix B}

Each weekly session follows a similar meeting format. Table B1 outlines the activities and the amount of time for each activity in a meeting agenda.

Table B1. Sample Agenda and Meeting Format

\begin{tabular}{|c|l|}
\hline Time in Minutes & \multicolumn{1}{|c|}{ Activity } \\
\hline 5 & Welcome and review agenda \\
\hline 25 & Light meal \\
\hline 2 & Parents, children (0-3 years and 4-8 years), and youth meet separately \\
\hline 3 & Nutrition and healthy living tip for parents and youth \\
\hline 65 & $\begin{array}{l}\text { Lesson/activities (parents complete retrospective pre-test/post-test the last 3 } \\
\text { minutes of parent lesson) }\end{array}$ \\
\hline 2 & Parents, children, and youth gather for family activity \\
\hline 18 & Family activity \\
\hline
\end{tabular}


Journal of Youth Development | http://jyd.pitt.edu/ | Vol. 13 Issue 3 DOI 10.5195/jyd.2018.620

Family Violence Prevention Program

\section{Appendix C}

Table C1 lists online resources that may provide youth development professionals more information on youth exposure to DV and strategies to address DV in communities. Ommission of pertinent resources was unintentional.

Table C1. Domestic Violence Resources for Youth Development Professionals

\begin{tabular}{|c|c|}
\hline Resource & Website \\
\hline Centers for Disease Control and Prevention & $\begin{array}{l}\text { https://www.cdc.gov/violenceprevention/intimatepa } \\
\text { rtnerviolence/ }\end{array}$ \\
\hline Futures Without Violence & www.futureswithoutviolence.org \\
\hline Minnesota Center Against Violence and Abuse & www.cehd.umn.edu/ssw/mincava \\
\hline National Center for Victims of Crime & www.victimsofcrime.org \\
\hline National Children's Advocacy Center & www.nationalcac.org \\
\hline National Coalition Against Domestic Violence & www.ncadv.org \\
\hline National Domestic Violence Hotline & www.thehotline.org \\
\hline $\begin{array}{l}\text { National Health Resource Center on Domestic } \\
\text { Violence }\end{array}$ & www.acf.hhs.gov/fysb/resource/nhrcdv \\
\hline National Indigenous Women's Resource Center & www.niwrc.org \\
\hline $\begin{array}{l}\text { National Institute of Justice, Office of Justice } \\
\text { Programs }\end{array}$ & $\begin{array}{l}\text { www.nij.gov/topics/crime/intimate-partner- } \\
\text { violence/teen-dating-violence/pages/welcome.aspx }\end{array}$ \\
\hline National Network to End Domestic Violence & https://nnedv.org \\
\hline National Resource Center on Domestic Violence & www.nrcdv.org \\
\hline National Sexual Violence Resource Center & www.nsvrc.org \\
\hline $\begin{array}{l}\text { National Violence Against Women Prevention } \\
\text { Research Center }\end{array}$ & https://mainweb-v.musc.edu/vawprevention/ \\
\hline $\begin{array}{l}\text { Praxis International: Battered Women's Justice } \\
\text { Project }\end{array}$ & www.bwjp.org \\
\hline $\begin{array}{l}\text { The NW Network of Bi, Trans, Lesbian and Gay } \\
\text { Survivors of Abuse }\end{array}$ & www.nwnetwork.org \\
\hline
\end{tabular}


Journal of Youth Development | http://jyd.pitt.edu/ | Vol. 13 Issue 3 DOI 10.5195/jyd.2018.620

Family Violence Prevention Program

Table C1 (continued).

\begin{tabular}{|l|l|}
\hline Resource & Website \\
\hline Prevent IPV - The IPV Prevention Council & $\underline{\text { https://preventipv.org }}$ \\
\hline Stalking Resource Center & $\underline{\text { ww.victimsofcrime.org }}$ \\
\hline Violence Against Women Electronic Network & $\underline{\text { https://vawnet.org }}$ \\
\hline $\begin{array}{l}\text { Workplaces Respond to Domestic and Sexual } \\
\text { Violence: A National Resource Center }\end{array}$ & $\underline{\text { www.workplacesrespond.org }}$ \\
\hline $\begin{array}{l}\text { World Health Organization/World Report on } \\
\text { Violence and Health }\end{array}$ & $\underline{\underline{h t t p: / / w w w . w h o . i n t / v i o l e n c e ~ i n j u r y ~ p r e v e n t i o n / v i o l ~}}$ \\
\hline
\end{tabular}

Youth and teens are the target audience for the dating violence prevention websites in Table C2.

Table C2. Domestic Violence Resources for Youth and Teens

\begin{tabular}{|c|c|}
\hline Resource & Website \\
\hline Break the Cycle & www.breakthecycle.org \\
\hline $\begin{array}{l}\text { Bursting the Bubble: Domestic Violence } \\
\text { Resource Center, Victoria, Australia }\end{array}$ & https://woah.org.au \\
\hline Centers for Disease Control and Prevention & $\begin{array}{l}\text { https://www.cdc.gov/violenceprevention/intimatepa } \\
\text { rtnerviolence/teen dating violence.html }\end{array}$ \\
\hline $\begin{array}{l}\text { Dating Abuse Resources for Teens: National } \\
\text { Domestic Violence Hotline }\end{array}$ & $\begin{array}{l}\text { http://www.thehotline.org/2013/02/25/dating- } \\
\text { abuse-resources-for-teens/ }\end{array}$ \\
\hline Do Something & $\begin{array}{l}\text { www.dosomething.org/us/facts/11-facts-about- } \\
\text { teen-dating-violence }\end{array}$ \\
\hline Love is Respect & www.loveisrespect.org \\
\hline $\begin{array}{l}\text { Safe Place for Youth . . . Someplace to Go. } \\
\text { Someone to Help }\end{array}$ & www.nationalsafeplace.org/teen-dating-violence \\
\hline That's Not Cool & https://thatsnotcool.com \\
\hline
\end{tabular}

